\title{
THE EFFECT OF UPPER RESPIRATORY ALLERGY ON ACUTE RESPIRATORY RESPONSE TO AMBIENT AIR POLLUTION DURING PHYSICAL EXERCISE
}

\author{
KRZYSZTOF KOCOT
}

\author{
Medical University of Silesia in Katowice, Katowice, Poland \\ Faculty of Medical Sciences in Katowice, Department of Epidemiology
}

\begin{abstract}
Objectives: Ambient air pollution is related to adverse respiratory effects. Because of a popular habit of recreational physical activity, the effects of exposure to increased levels of air pollution attract increasing attention. It remains unclear whether the allergy status has an impact on acute responses to air pollution exposure during brief exercise in young adults. The aim of the study was to determine if acute respiratory responses to ambient air pollution during physical exercise differ between young subjects with and without a history of upper respiratory allergy. Material and Methods: Overall, 41 young males with $(\mathrm{N}=15,36.6 \%)$ and without allergy $(\mathrm{N}=26,63.4 \%)$ performed short moderate-intensive cycle-ergometer sessions in winter air pollution exposure conditions. Associations were analyzed between environmental conditions and acute physiological changes in spirometry, fractioned exhaled nitric oxide (FeNO) levels, blood pressure and pulse oximetry. Results: No associations between air pollution concentrations and changes in forced vital capacity, forced expiratory volume in $1 \mathrm{~s}$ and the Tiffeneau index were found. In the subjects without allergy, the increased air pollution concentrations recorded during exercise were associated with a post-exercise increase/a smaller decrease in FeNO $\left(\mathrm{SO}_{2}:\right.$ Spearman's $\varrho=0.44$, NOx: $\varrho=0.51$, and particulate matter $[\mathrm{PM}]$ levels $-\mathrm{PM}_{10}: \mathrm{Q}=0.51, \mathrm{PM}_{25}: \mathrm{Q}=0.52$ ). This effect was not observed in the subjects with allergy. Conclusions: Upper-respiratory allergy may be a modifying factor in human response to air pollution during exercise. Exposure to air pollution during brief moderate-intensive exercise did not have any acute negative impact on respiratory and cardiovascular function in young males. However, in the case of FeNO, subclinical post-exercise changes related to air pollution were observed in volunteers without allergy. Int J Occup Med Environ Health. 2020;33(5):649-60
\end{abstract}

Key words:

air pollution, exercise, spirometry, particulate matter, nitric oxide, hypersensitivity

\section{INTRODUCTION}

Epidemiological findings have shown that chronic exposure to ambient air pollution is associated with more frequent respiratory symptoms and impaired lung function, although the magnitude of decline in airflow is small and depends on the level of exposure [1,2]. The most convincing association was found in relation to particulate matter (PM), a key indicator of air pollution, which is a complex group of solid and liquid particles, transporting multiple toxic substances [2,3]. Exposure to PM may induce and maintain inflammatory processes in the airways, resulting in respiratory function impairment [2].

Less is known about the short-term responses of lung function to increased levels of particulate and gaseous air pollution in healthy adults. Published reports focus on the spirometric responses and show that exposure to

Funding: this study was supported by the Medical University of Silesia in Katowice (intramural grant No. KNW-1-154/K/9/0 entitled "Epidemiological assessment of basic health problems in the population of Silesian Voivodship", project manager: Prof. Jan E. Zejda).

Received: August 27, 2019. Accepted: May 10, 2020.

Corresponding author: Krzysztof Kocot, Medical University of Silesia in Katowice, Faculty of Medical Sciences in Katowice, Department of Epidemiology, Medyków 18, 40-752 Katowice, Poland (e-mail: kjkocot@gmail.com). 
air pollution during exercise may result in a reduction of forced vital capacity (FVC), forced expiratory volume in $1 \mathrm{~s}$ $\left(\mathrm{FEV}_{1}\right)$ and the $\mathrm{FEV}_{1} / \mathrm{FVC}$ ratio or the Tiffeneau index $\left(\mathrm{FEV}_{1} \% \mathrm{FVC}\right)$ [4]. Another respiratory function marker of interest is fractioned exhaled nitric oxide (FeNO). It is considered to be a sensitive marker of eosinophilic airways inflammation and has been used in a number of studies assessing air pollution inflammatory impact [5].

The effects of exposure to increased levels of ambient air pollution have recently attracted more attention because of a popular habit of recreational physical activity. Such outdoor activities as jogging or cycling increase the ventilation rate and may result in increased deposition of ambient air pollutants in the respiratory tract $[4,6]$. A number of studies have indicated that air pollution may impair exercise performance and reduce the positive effects of physical activity on respiratory and cardiovascular function [7-9]. However, the results obtained in young adults show that, with the increase in the physical activity level, the negative physiological changes induced by air pollution can be lessened [10-12].

It cannot be excluded that the described distribution of acute respiratory responses following physical exercise reflects the range of ambient air pollution levels. In Upper Silesia, Poland, the concentrations of particulate and gaseous pollutants are high and during the heating season they usually exceed the limit values. For example, the mean $\mathrm{PM}_{2.5}$ concentration in winter 2017 in Katowice was $45 \mu \mathrm{g} / \mathrm{m}^{3}$ (the Polish annual limit value $-25 \mu \mathrm{g} / \mathrm{m}^{3}$, the WHO guideline $\left.-10 \mu \mathrm{g} / \mathrm{m}^{3}\right)[13,14]$. This is why the author conducted a study on acute respiratory responses to air pollution during controlled physical exercise in young male subjects. All the subjects were volunteers without chronic respiratory, circulatory, metabolic or musculoskeletal diseases. However, the study group included subjects who had a history of upper respiratory allergy allergic rhinitis and/or conjunctivitis without current medication or symptoms during the study period. Results ob- tained in those subjects provided an opportunity to assess a potential effect of allergy on the respiratory responses to a short-term physical exercise, performed under exposure to high levels of ambient air pollution.

The objective of the study was to determine if acute respiratory responses to ambient air pollution during physical exercise would differ between young subjects with and without a history of upper respiratory allergy.

\section{MATERIAL AND METHODS}

\section{Study area}

The study was conducted in November 2018-March 2019 in Katowice. Katowice is a centre of the Silesian Agglomeration, a highly populated area in the south of Poland, where air pollution is still a current health problem. In 2017, the average annual level of $\mathrm{PM}_{10}$ was $52 \mu \mathrm{g} / \mathrm{m}^{3}$ and the Polish 24-h average limit value $\left(40 \mu \mathrm{g} / \mathrm{m}^{3}\right)$ was exceeded on 102 days [14].

\section{Participants}

The study participants were recruited from students of the Medical University of Silesia. Eligible volunteers were healthy male adults, aged 18-30 years. The exclusion criteria included chronic respiratory (e.g., asthma), circulatory, metabolic and musculoskeletal diseases, but not allergic rhinitis or conjunctivitis (declared in the qualification questionnaire). Other exclusion criteria were current infections, the presence of respiratory symptoms or anti-allergic medication use up to 2 weeks prior to the study.

\section{Study design}

For the purpose of the study, each participant had to visit the Department of Epidemiology of the Medical University of Silesia, where the study was conducted. During the visit, the participants filled out a qualification questionnaire designed to assess their health, physical activity and lifestyle habits. If the inclusion criteria were met, they were measured and weighed, and the baseline measure- 
ments of blood pressure, pulse oximetry, spirometry and FeNO were collected. Each subject performed a steadystate submaximal exercise on a cycle ergometer for $15 \mathrm{~min}$. Directly after the exercise, the author repeated the measurements of blood pressure, pulse oximetry, spirometry and FeNO. All these measurements were taken in a room with controlled room temperature and closed windows. The participants exercised in a separate room, where the heating was turned off and windows were opened, in order to provide outdoor exposure conditions. Actually, because of the very close location of the ergometer to the open window, the subjects inhaled outdoor air.

\section{Environmental monitoring}

For the purpose of exposure monitoring, the author recorded several air pollution and weather parameters. During the exercise, the temperature and humidity were controlled in the cycle ergometer room. In the same place, during exercise time, the concentration of PM with the diameter of $<10 \mu \mathrm{g}\left(\mathrm{PM}_{10}\right)$ was monitored using TSI SidePak AM520 equipment. Additional data on air pollutant levels $\left(\mathrm{PM}_{2.5}, \mathrm{SO}_{2}, \mathrm{NO}_{\mathrm{x}}\right)$ reflected area concentrations and were collected from the Inspectorate of Environmental Protection station located $4 \mathrm{~km}$ away from the place of the study. These data were also used to calculate longer lags of exposure: $3 \mathrm{~h}$ and $24 \mathrm{~h}$ prior to the study period.

\section{Health measurements}

Health measurements were taken in 2 sessions: before the exercise (measurement 1-baseline) and directly after the exercise (measurement 2 - post-exercise), always in the same order: blood pressure alongside with pulse oximetry, spirometry and FeNO measurements. Blood pressure was measured in a sitting position with the automatic OMRON M2 Basic device (OMRON Healthcare, Hoofddorp, the Netherlands), with the cuff on the right arm. Each time, 3 measurements were taken and their average value was recorded. Spirometry was performed according to the guidelines of the European
Respiratory Society (ERS) and the American Thoracic Society (ATS) with an EasyOne spirometer (NDD, Zurich, Switzerland). The participants repeated maneuvers until they met the ERS/ATS acceptability and repeatability criteria (at least 3 acceptable maneuvers, the best 2 values of $\mathrm{FEV}_{1}$ and FVC within $150 \mathrm{ml}$ or $5 \%$ of each other) or the maximum number of maneuvers (8) was achieved. If the criteria were not met, such spirometry was not taken into consideration in the statistical analysis. Results of spirometry were expressed in absolute terms and in percent of predicted values (\%PV). Predicted values were given according to ERS'93 equations, and FeNO was measured with a portable NIOX Mino device (Aerocrine AB, Solna, Sweden) according to the ATS/ERS standardized procedures during steady 10 -s expiration after maximal inhalation.

\section{Exercise}

The participants exercised after the completion of baseline measurements, with the use of a cycle ergometer, in a room that provided outdoor conditions, as mentioned above. In order to standardize the level of exertion for all participants, the heart rate of each volunteer was controlled during exercise. The ergometer power (initially $60 \mathrm{~W}$ ) was increased in order to reach the heart rate of $\geq 70 \%$ of the volunteer's maximum heart rate, calculated using the following equation:

$$
\mathrm{HR}_{\max }=220-\text { age }
$$

within the first $3 \mathrm{~min}$. The exercise was then continued up to $15 \mathrm{~min}$. Immediately after the end of the exercise, the participants moved to the health measurement room for post-exercise measurements.

\section{Ethics}

The study protocol was accepted by the Ethics Committee of the Medical University of Silesia in Katowice. Each participant gave his informed consent before the study. 


\section{Statistical analysis}

Data were analyzed with Statistica 13 and SAS 9.4 software. Categorical variables were presented as proportions, and for continuous variables the average value, standard deviation and min./max values were calculated. Normality of distribution was assessed using the Shapiro-Wilk test. The difference between baseline (before exercise) and post-exercise measurements of physiologic variables was calculated as the relative difference, according to the formula:

$$
\frac{\text { post-exercise }- \text { baseline }}{\text { baseline }}
$$

therefore, the relative difference $>0$ means post-exercise increase and $<0$ post-exercise decrease. Comparisons of dependent variables were done with paired Student's t-test and the Wilcoxon test, for parametric and non-parametric variables, respectively, while for comparisons of independent variables Student's t-test or the Mann-Whitney $\mathrm{U}$ test was used. Qualitative variables were compared between the groups with Pearson's $\varphi^{2}$ test or the Fisher test. The correlation analysis was done using Spearman's rankorder correlation. The statistical significance was based on the criterion of $\mathrm{p}<0.05$.

\section{RESULTS}

\section{Study group characteristics}

In November 2018-March 2019, 41 young male volunteers were examined. The group included $15(36.6 \%)$ men with, and $26(63.4 \%)$ men without, allergy. The subjects were aged 18-27 years (Me: 23.0 \pm 2.2 years), and their body mass index ranged $17.8-32.6 \mathrm{~kg} / \mathrm{m}^{2}$ (Me: $\left.23.7 \pm 3.1 \mathrm{~kg} / \mathrm{m}^{2}\right)$. Table 1 shows anthropometric variables and Table 2 the results of environmental measurements recorded during the study period and calculated as the arithmetic mean, the median and the range of all measurements obtained during all exercise sessions, according to the allergy status of the subjects.

The differences in exercising patterns between the volunteers with and without allergy were not statistically significant. However, it is worth to notice that most of the participants with allergy declared that their condition was good or very good, and avoided exercising outdoors when air quality was bad. Additional information on exercise behaviors is shown in Table 3.

According to the anthropometric variables, there were no differences between the 2 groups. The comparison of air quality measurements obtained during exercise sessions of the subjects without allergy with respective measurements obtained during exercise sessions of the subjects with allergy showed that there were no significant differences in

Table 1. Anthropometric variables of young male volunteers aged 18-30 years, taking part in the study on acute respiratory

\begin{tabular}{|c|c|c|c|c|c|c|c|}
\hline \multirow{3}{*}{ Variable } & \multicolumn{6}{|c|}{$\begin{array}{l}\text { Participants } \\
(\mathrm{N}=41)\end{array}$} & \multirow{3}{*}{$\mathrm{p}^{*}$} \\
\hline & \multicolumn{3}{|c|}{$\begin{array}{l}\text { without allergy } \\
\qquad(\mathrm{N}=26)\end{array}$} & \multicolumn{3}{|c|}{$\begin{array}{l}\text { with allergy } \\
(\mathrm{N}=15)\end{array}$} & \\
\hline & $\mathrm{M} \pm \mathrm{SD}$ & $\mathrm{Me}$ & $\min .-\max$ & $\mathrm{M} \pm \mathrm{SD}$ & $\mathrm{Me}$ & $\min .-\max$ & \\
\hline Age [years] & $22.9 \pm 1.6$ & 23.0 & $19.0-26.0$ & $23.0 \pm 3.0$ & 24.0 & $18.0-27.0$ & 0.9 \\
\hline Height $[\mathrm{cm}]$ & $179.8 \pm 4.6$ & 179.5 & $171.0-189.0$ & $181.1 \pm 6.9$ & 179.0 & $173.0-197.0$ & 0.4 \\
\hline Body mass $[\mathrm{kg}]$ & $76.5 \pm 10.4$ & 76.5 & $54.6-99.0$ & $79.5 \pm 13.7$ & 80.0 & $58.0-100.0$ & 0.4 \\
\hline BMI $\left[\mathrm{kg} / \mathrm{m}^{2}\right]$ & $23.7 \pm 3.1$ & 23.7 & $17.8-31.0$ & $24.2 \pm 4.0$ & 24.0 & $18.0-32.6$ & 0.6 \\
\hline
\end{tabular}
responses to ambient air pollution during physical exercise, Katowice, Poland, November 2018-March 2019

* Results of Student's t-test/Mann-Whitney U test. 
Table 2. Results of air quality measurements obtained during exercise sessions by young male volunteers aged 18-30 years, taking part in the study on acute respiratory responses to ambient air pollution during physical exercise, Katowice, Poland, November 2018-March 2019

\begin{tabular}{|c|c|c|c|c|c|c|c|}
\hline \multirow{3}{*}{ Variable } & \multicolumn{6}{|c|}{ Air quality measurements } & \multirow{3}{*}{$\mathrm{p}^{*}$} \\
\hline & \multicolumn{3}{|c|}{$\begin{array}{l}\text { participants without allergy } \\
\qquad(\mathrm{N}=26)\end{array}$} & \multicolumn{3}{|c|}{$\begin{array}{l}\text { participants with allergy } \\
\qquad(\mathrm{N}=15)\end{array}$} & \\
\hline & $\mathrm{M} \pm \mathrm{SD}$ & $\mathrm{Me}$ & $\min .-\max$ & $\mathrm{M} \pm \mathrm{SD}$ & $\mathrm{Me}$ & $\min .-\max$ & \\
\hline Temperature $\left[{ }^{\circ} \mathrm{C}\right]$ & $0.7 \pm 5.0$ & 1.0 & $-6.0-8.0$ & $-0.3 \pm 3.7$ & 0.0 & $-6.0-6.0$ & 0.6 \\
\hline Relative humidity [\%] & $71.5 \pm 15.4$ & 77.5 & $39.0-94.0$ & $76.3 \pm 8.2$ & 76.0 & $66.0-91.0$ & 0.5 \\
\hline Wind speed $[\mathrm{m} / \mathrm{s}]$ & $3.2 \pm 1.8$ & 3.0 & $1.0-6.5$ & $3.0 \pm 1.1$ & 3.0 & $1.5-5.0$ & 0.9 \\
\hline $\mathrm{SO}_{2}\left[\mu \mathrm{g} / \mathrm{m}^{3}\right]$ & $21.9 \pm 22.1$ & 11.7 & $5.3-85.8$ & $20.2 \pm 11.6$ & 17.6 & $4.9-41.7$ & 0.4 \\
\hline $\mathrm{NO}_{\mathrm{x}}\left[\mu \mathrm{g} / \mathrm{m}^{3}\right]$ & $88.4 \pm 87.4$ & 48.0 & $20.0-346.0$ & $105.7 \pm 93.4$ & 98.0 & $34.0-421.0$ & 0.1 \\
\hline $\mathrm{PM}_{10}\left[\mu \mathrm{g} / \mathrm{m}^{3}\right]$ & $121.9 \pm 138.8$ & 60.7 & $5.0-635.5$ & $150.2 \pm 101.2$ & 127.3 & $20.4-387.0$ & 0.2 \\
\hline $\mathrm{PM}_{25}\left[\mu \mathrm{g} / \mathrm{m}^{3}\right]$ & $53.6 \pm 41.2$ & 38.5 & $12.0-150.0$ & $63.4 \pm 38.0$ & 54.0 & $18.0-157.0$ & 0.3 \\
\hline
\end{tabular}

* Results of Student's t-test/Mann-Whitney U test.

Table 3. Exercise behaviors of the allergic and non-allergic groups of young male volunteers aged 18-30 years, taking part in the study on acute respiratory responses to ambient air pollution during physical exercise, Katowice, Poland, November 2018-March 2019

\begin{tabular}{lccc}
\hline \multicolumn{1}{c}{ Variable } & \multicolumn{2}{c}{$\begin{array}{c}\text { Participants } \\
(\mathrm{N}=41) \\
\end{array}$} & \multicolumn{2}{c}{$[\mathrm{n}(\%)]$} & $\mathrm{p}^{*}$ \\
\cline { 2 - 3 } & $\begin{array}{c}\text { without allergy } \\
(\mathrm{N}=26)\end{array}$ & $\begin{array}{c}\text { with allergy } \\
(\mathrm{N}=15)\end{array}$ & \\
\hline Exercise time at least 1 h/day & $12(46.2)$ & $8(53.3)$ & 0.6 \\
Self-perceived condition: good or very good & $13(50.0)$ & $12(80.0)$ & 0.06 \\
Outdoor exercise during winter season & $5(19.2)$ & $3(20.0)$ & 0.6 \\
Avoiding outdoor exercise when air quality is poor & $13(50.0)$ & $10(66.7)$ & 0.3 \\
\hline
\end{tabular}

* Results of Pearson's $\chi^{2}$ test/Fisher test.

environmental conditions. Although on the study days, some showed low levels of air pollution, the average concentrations of $\mathrm{SO}_{2}, \mathrm{PM}_{10}$ and $\mathrm{PM}_{2.5}$ exceeded the current WHO air quality guidelines reference values. The $\mathrm{PM}_{10}$ concentrations of $>50 \mu \mathrm{g} / \mathrm{m}^{3}$, as recommended by WHO, were recorded during 31 sessions (75.6\%).

All baseline lung function measurements were within the normal values - FVC: 102.9 $\pm 7.8 \%$ PV vs. $99.1 \pm 8.9 \% \mathrm{PV}, \quad \mathrm{FEV}_{1}: 103.4 \pm 10.8 \% \mathrm{PV}$ vs. $100.9 \pm 6.1 \% \mathrm{PV}$, and $\mathrm{FEV}_{1} \% \mathrm{FVC}: 102.4 \pm 8.0 \% \mathrm{PV}$ vs.
$103.9 \pm 5.9 \% \mathrm{PV}$ in the subjects without and with allergy, respectively. Table 4 shows the results of baseline and post-exercise physiological measurements obtained in the subjects divided according to the allergy status. Comparisons of the results of the 2 groups did not show statistically significant differences. However, a generally greater decrease in terms of spirometry parameters, apart from FVC, and smaller in the case of FeNO, could be noted in the volunteers with a history of allergy. Several differences were noted when comparing the results of baseline with 
Table 4. Results of baseline and post-exercise measurements obtained in young male volunteers aged 18-30 years, taking part in the study on acute respiratory responses to ambient air pollution during physical exercise, Katowice, Poland, November 2018-March 2019

\begin{tabular}{|c|c|c|c|c|c|c|c|c|}
\hline \multirow[b]{2}{*}{ Variable } & \multicolumn{4}{|c|}{$\begin{array}{l}\text { Participants without allergy } \\
\qquad(\mathrm{N}=26)\end{array}$} & \multicolumn{4}{|c|}{$\begin{array}{l}\text { Participants with allergy } \\
\qquad(\mathrm{N}=15)\end{array}$} \\
\hline & $\begin{array}{l}\text { baseline } \\
(\mathrm{M} \pm \mathrm{SD})\end{array}$ & $\begin{array}{l}\text { post-exercise } \\
(\mathrm{M} \pm \mathrm{SD})\end{array}$ & $\begin{array}{c}\text { relative } \\
\text { difference } \\
\Delta \% \\
(\mathrm{M} \pm \mathrm{SD})\end{array}$ & $\mathrm{p}^{*}$ & $\begin{array}{l}\text { baseline } \\
(\mathrm{M} \pm \mathrm{SD})\end{array}$ & $\begin{array}{l}\text { post-exercise } \\
(\mathrm{M} \pm \mathrm{SD})\end{array}$ & $\begin{array}{c}\text { relative } \\
\text { difference } \\
{[\Delta \%]} \\
(\mathrm{M} \pm \mathrm{SD})\end{array}$ & $\mathrm{p}^{*}$ \\
\hline FVC [1] & $5.51 \pm 0.44$ & $5.51 \pm 0.49$ & $-0.13 \pm 3.75$ & 0.8 & $5.36 \pm 0.56$ & $5.40 \pm 0.50$ & $0.83 \pm 4.31$ & 0.7 \\
\hline $\mathrm{FEV}_{1}[1]$ & $4.66 \pm 0.52$ & $4.65 \pm 0.52$ & $-0.33 \pm 2.79$ & 0.5 & $4.59 \pm 0.38$ & $4.54 \pm 0.42$ & $-0.99 \pm 5.85$ & 0.4 \\
\hline $\mathrm{FEV}_{1} \% \mathrm{FVC}[\%]$ & $84.71 \pm 6.67$ & $84.56 \pm 6.95$ & $-0.13 \pm 3.09$ & 0.8 & $85.90 \pm 4.85$ & $84.35 \pm 6.12$ & $-1.84 \pm 3.07$ & 0.04 \\
\hline $\operatorname{PEF}[1 / \mathrm{s}]$ & $10.00 \pm 1.77$ & $9.88 \pm 1.58$ & $0.05 \pm 8.23$ & 0.7 & $9.88 \pm 1.25$ & $9.78 \pm 1.00$ & $-0.61 \pm 8.38$ & 0.6 \\
\hline \multicolumn{9}{|l|}{$\operatorname{MEF}[1 / s]$} \\
\hline $\mathrm{MEF}_{75}$ & $8.76 \pm 1.67$ & $8.48 \pm 1.61$ & $-1.78 \pm 6.16$ & 0.1 & $8.77 \pm 1.10$ & $8.20 \pm 1.42$ & $-6.76 \pm 9.41$ & 0.01 \\
\hline $\mathrm{MEF}_{50}$ & $5.92 \pm 1.62$ & $5.76 \pm 1.62$ & $-2.40 \pm 8.37$ & 0.1 & $5.97 \pm 1.30$ & $5.56 \pm 1.04$ & $-5.41 \pm 14.00$ & 0.08 \\
\hline $\mathrm{MEF}_{25}$ & $2.69 \pm 0.80$ & $2.60 \pm 0.88$ & $-3.44 \pm 14.14$ & 0.2 & $2.67 \pm 0.76$ & $2.55 \pm 0.95$ & $-5.23 \pm 17.40$ & 0.3 \\
\hline $\mathrm{MEF}_{25-75}$ & $4.95 \pm 1.18$ & $4.85 \pm 1.19$ & $-2.25 \pm 5.15$ & 0.03 & $5.10 \pm 1.00$ & $4.81 \pm 1.19$ & $-6.14 \pm 9.53$ & 0.03 \\
\hline FeNO [ppb] & $27.91 \pm 9.21$ & $26.09 \pm 8.28$ & $-5.40 \pm 13.58$ & 0.04 & $33.67 \pm 23.35$ & $32.13 \pm 20.15$ & $-1.60 \pm 10.37$ & 0.7 \\
\hline \multicolumn{9}{|l|}{$\mathrm{BP}[\mathrm{mm} \mathrm{Hg}]$} \\
\hline SBP & $120.73 \pm 8.84$ & $131.20 \pm 9.18$ & $9.10 \pm 9.75$ & $<0.001$ & $124.09 \pm 7.32$ & $134.44 \pm 8.20$ & $8.47 \pm 5.49$ & $<0.001$ \\
\hline DBP & $68.91 \pm 5.88$ & $70.92 \pm 6.55$ & $3.28 \pm 9.49$ & 0.1 & $69.22 \pm 6.03$ & $74.02 \pm 4.45$ & $7.36 \pm 6.88$ & 0.001 \\
\hline HR [bpm] & $77.12 \pm 10.68$ & $102.63 \pm 14.63$ & $24.35 \pm 8.80$ & $<0.001$ & $74.37 \pm 11.35$ & $97.07 \pm 13.95$ & $22.90 \pm 9.99$ & $<0.001$ \\
\hline $\mathrm{SpO}_{2}[\%]$ & $97.65 \pm 1.06$ & $96.77 \pm 0.99$ & $-0.90 \pm 1.12$ & 0.001 & $97.93 \pm 1.16$ & $96.73 \pm 0.80$ & $-1.21 \pm 1.44$ & 0.01 \\
\hline
\end{tabular}

DBP - diastolic blood pressure; FeNO - fractioned exhaled nitric oxide; $\mathrm{FEV}_{1}$ - forced expiratory volume in $1 \mathrm{~s} ; \mathrm{FEV}_{1} \% \mathrm{FVC}$ - Tiffeneau index;

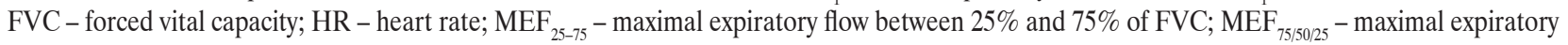
flow at 75/50/25\% of FVC; PEF - peek expiratory flow; SBP - systolic blood pressure; $\mathrm{SpO}_{2}$ - oxygen saturation.

* Result of paired Student's t-test/Wilcoxon test.

post-exercise measurements within the groups. Only in the allergic group, the $\mathrm{FEV}_{1} \% \mathrm{FVC}$ index was significantly lower after exercise than at baseline. In contrast, FeNO after exercise was significantly lower than at baseline only in the non-allergic group.

The analysis of the correlations between environmental parameters recorded at the time of the study and post-exercise changes in physiological parameters showed further differences between the groups. Only in the non-allergic group, the correlations between changes in the maximal expiratory flow at $75 \%$, FeNO, diastolic blood pressure and environmental conditions were statistically significant.
In the case of FeNO, strong positive correlations with air humidity, PM and NOx concentrations, and a negative correlation with wind speed, were observed only in the nonallergic group. The analysis for longer lags of exposure (3-h and 24-h moving averages) showed no significant correlations (data not shown). A single observation with particularly high baseline and post-exercise FeNO levels caused a high standard deviation of FeNO values in the allergic group (Table 4). However, the results remained unaffected when this observation was excluded (data not shown). A complete correlation analysis in the allergic and non-allergic groups is presented in Table 5. 
Table 5. Correlations of relative differences ("post-exercise" - "baseline"/“baseline") in physiological parameters with air pollutants and weather conditions recorded at the time of the study on acute respiratory responses to ambient air pollution during physical exercise, Katowice, Poland, November 2018-March 2019

\begin{tabular}{|c|c|c|c|c|c|c|c|}
\hline \multirow{3}{*}{ Parameter } & \multicolumn{7}{|c|}{ Correlation } \\
\hline & \multicolumn{3}{|c|}{ weather conditions } & \multicolumn{4}{|c|}{ air pollutants } \\
\hline & temperature & $\begin{array}{l}\text { relative } \\
\text { humidity }\end{array}$ & wind speed & $\mathrm{SO}_{2}$ & $\mathrm{NO}_{x}$ & $\mathrm{PM}_{10}$ & $\mathrm{PM}_{2.5}$ \\
\hline \multicolumn{8}{|l|}{$\Delta \mathrm{FVC}$} \\
\hline \multicolumn{8}{|l|}{$\mathrm{N}$} \\
\hline $\mathrm{R}$ & -0.13 & 0.10 & -0.35 & 0.30 & 0.13 & 0.19 & 0.25 \\
\hline $\mathrm{p}$ & 0.5 & 0.6 & 0.1 & 0.1 & 0.5 & 0.3 & 0.2 \\
\hline \multicolumn{8}{|l|}{ A } \\
\hline $\mathrm{R}$ & 0.05 & 0.09 & -0.37 & 0.14 & 0.20 & 0.32 & 0.15 \\
\hline $\mathrm{p}$ & 0.8 & 0.7 & 0.1 & 0.6 & 0.4 & 0.2 & 0.6 \\
\hline \multicolumn{8}{|l|}{$\Delta \mathrm{FEV}_{1}$} \\
\hline \multicolumn{8}{|l|}{$\mathrm{N}$} \\
\hline $\mathrm{R}$ & -0.08 & 0.11 & -0.23 & 0.10 & 0.15 & 0.19 & 0.09 \\
\hline $\mathrm{p}$ & 0.7 & 0.6 & 0.2 & 0.6 & 0.4 & 0.3 & 0.6 \\
\hline \multicolumn{8}{|l|}{ A } \\
\hline $\mathrm{R}$ & -0.10 & -0.06 & 0.18 & 0.13 & 0.26 & 0.24 & 0.16 \\
\hline $\mathrm{p}$ & 0.7 & 0.8 & 0.05 & 0.6 & 0.3 & 0.4 & 0.5 \\
\hline \multicolumn{8}{|l|}{$\Delta \mathrm{FEV}_{1} / \mathrm{FVC}$} \\
\hline \multicolumn{8}{|l|}{$\mathrm{N}$} \\
\hline $\mathrm{R}$ & -0.03 & -0.01 & 0.20 & -0.26 & -0.04 & -0.15 & -0.21 \\
\hline $\mathrm{p}$ & 0.8 & 0.9 & 0.3 & 0.2 & 0.8 & 0.4 & 0.3 \\
\hline \multicolumn{8}{|l|}{ A } \\
\hline $\mathrm{R}$ & 0.05 & -0.40 & 0.07 & -0.07 & 0.02 & 0.00 & -0.04 \\
\hline $\mathrm{p}$ & 0.8 & 0.1 & 0.8 & 0.8 & 0.9 & 0.9 & 0.9 \\
\hline \multicolumn{8}{|l|}{$\triangle \mathrm{PEF}$} \\
\hline \multicolumn{8}{|l|}{$\mathrm{N}$} \\
\hline $\mathrm{R}$ & 0.30 & -0.19 & -0.13 & -0.19 & 0.06 & -0.11 & -0.14 \\
\hline $\mathrm{p}$ & 0.1 & 0.3 & 0.5 & 0.3 & 0.7 & 0.6 & 0.5 \\
\hline \multicolumn{8}{|l|}{ A } \\
\hline $\mathrm{R}$ & 0.09 & 0.30 & 0.08 & 0.14 & 0.26 & 0.16 & 0.09 \\
\hline $\mathrm{p}$ & 0.7 & 0.2 & 0.7 & 0.6 & 0.3 & 0.5 & 0.7 \\
\hline \multicolumn{8}{|l|}{$\Delta \mathrm{MEF}_{75}$} \\
\hline \multicolumn{8}{|l|}{$\mathrm{N}$} \\
\hline $\mathrm{R}$ & -0.39 & 0.56 & 0.05 & 0.37 & 0.44 & 0.42 & 0.43 \\
\hline $\mathrm{p}$ & 0.06 & 0.004 & 0.8 & 0.07 & 0.03 & 0.04 & 0.04 \\
\hline
\end{tabular}


Table 5. Correlations of relative differences ("post-exercise" - "baseline"/“baseline") in physiological parameters with air pollutants and weather conditions recorded at the time of the study on acute respiratory responses to ambient air pollution during physical exercise, Katowice, Poland, November 2018-March 2019 - cont.

\begin{tabular}{|c|c|c|c|c|c|c|c|}
\hline \multirow{3}{*}{ Parameter } & \multicolumn{7}{|c|}{ Correlation } \\
\hline & \multicolumn{3}{|c|}{ weather conditions } & \multicolumn{4}{|c|}{ air pollutants } \\
\hline & temperature & $\begin{array}{l}\text { relative } \\
\text { humidity }\end{array}$ & wind speed & $\mathrm{SO}_{2}$ & $\mathrm{NO}_{x}$ & $\mathrm{PM}_{10}$ & $\mathrm{PM}_{2.5}$ \\
\hline \multicolumn{8}{|l|}{$\Delta \mathrm{MEF}_{75}-$ cont. } \\
\hline \multicolumn{8}{|l|}{ A } \\
\hline $\mathrm{R}$ & 0.05 & 0.08 & 0.13 & 0.28 & 0.15 & 0.10 & 0.17 \\
\hline $\mathrm{p}$ & 0.8 & 0.7 & 0.6 & 0.3 & 0.5 & 0.7 & 0.5 \\
\hline \multicolumn{8}{|l|}{$\Delta \mathrm{MEF}_{50}$} \\
\hline \multicolumn{8}{|l|}{$\mathrm{N}$} \\
\hline $\mathrm{R}$ & -0.21 & 0.12 & 0.06 & 0.20 & 0.30 & 0.37 & 0.26 \\
\hline $\mathrm{p}$ & 0.3 & 0.5 & 0.7 & 0.3 & 0.1 & 0.08 & 0.2 \\
\hline \multicolumn{8}{|l|}{ A } \\
\hline $\mathrm{R}$ & 0.23 & -0.36 & -0.42 & 0.01 & -0.06 & 0.19 & 0.00 \\
\hline $\mathrm{p}$ & 0.4 & 0.1 & 0.1 & 0.9 & 0.8 & 0.4 & 0.9 \\
\hline \multicolumn{8}{|l|}{$\Delta \mathrm{MEF}_{25}$} \\
\hline \multicolumn{8}{|l|}{$\mathrm{N}$} \\
\hline $\mathrm{R}$ & -0.26 & 0.21 & -0.23 & 0.12 & 0.23 & 0.22 & 0.08 \\
\hline $\mathrm{p}$ & 0.2 & 0.3 & 0.2 & 0.5 & 0.2 & 0.3 & 0.7 \\
\hline \multicolumn{8}{|l|}{$\mathrm{A}$} \\
\hline $\mathrm{R}$ & -0.10 & -0.41 & -0.08 & -0.04 & 0.08 & 0.04 & 0.00 \\
\hline $\mathrm{p}$ & 0.7 & 0.1 & 0.7 & 0.8 & 0.7 & 0.8 & 0.9 \\
\hline \multicolumn{8}{|l|}{$\Delta \mathrm{MEF}_{25-75}$} \\
\hline \multicolumn{8}{|l|}{$\mathrm{N}$} \\
\hline $\mathrm{R}$ & -0.22 & 0.18 & 0.01 & 0.01 & 0.22 & 0.14 & 0.07 \\
\hline $\mathrm{p}$ & 0.3 & 0.4 & 0.9 & 0.9 & 0.3 & 0.5 & 0.7 \\
\hline \multicolumn{8}{|l|}{ A } \\
\hline $\mathrm{R}$ & 0.14 & -0.37 & -0.11 & -0.01 & 0.13 & 0.11 & 0.04 \\
\hline $\mathrm{p}$ & 0.6 & 0.1 & 0.7 & 0.9 & 0.6 & 0.6 & 0.8 \\
\hline \multicolumn{8}{|l|}{$\Delta \mathrm{FeNO}$} \\
\hline \multicolumn{8}{|l|}{$\mathrm{N}$} \\
\hline $\mathrm{R}$ & -0.20 & 0.57 & -0.50 & 0.44 & 0.51 & 0.51 & 0.52 \\
\hline $\mathrm{p}$ & 0.3 & 0.01 & 0.02 & 0.04 & 0.02 & 0.01 & 0.01 \\
\hline \multicolumn{8}{|l|}{ A } \\
\hline $\mathrm{R}$ & -0.31 & 0.17 & -0.36 & -0.08 & 0.06 & 0.13 & -0.01 \\
\hline $\mathrm{p}$ & 0.2 & 0.5 & 0.1 & 0.7 & 0.8 & 0.6 & 0.9 \\
\hline
\end{tabular}


Table 5. Correlations of relative differences ("post-exercise" - "baseline"/"baseline") in physiological parameters with air pollutants and weather conditions recorded at the time of the study on acute respiratory responses to ambient air pollution during physical exercise, Katowice, Poland, November 2018-March 2019 - cont.

\begin{tabular}{|c|c|c|c|c|c|c|c|}
\hline \multirow{3}{*}{ Parameter } & \multicolumn{7}{|c|}{ Correlation } \\
\hline & \multicolumn{3}{|c|}{ weather conditions } & \multicolumn{4}{|c|}{ air pollutants } \\
\hline & temperature & $\begin{array}{l}\text { relative } \\
\text { humidity }\end{array}$ & wind speed & $\mathrm{SO}_{2}$ & $\mathrm{NO}_{\mathrm{x}}$ & $\mathrm{PM}_{10}$ & $\mathrm{PM}_{2.5}$ \\
\hline \multicolumn{8}{|l|}{$\Delta \mathrm{SBP}$} \\
\hline \multicolumn{8}{|l|}{$\mathrm{N}$} \\
\hline $\mathrm{R}$ & 0.13 & -0.17 & 0.00 & -0.02 & 0.05 & 0.18 & -0.08 \\
\hline $\mathrm{p}$ & 0.5 & 0.4 & 0.9 & 0.9 & 0.8 & 0.3 & 0.7 \\
\hline \multicolumn{8}{|l|}{ A } \\
\hline $\mathrm{R}$ & -0.46 & 0.10 & -0.31 & 0.36 & 0.39 & 0.28 & 0.38 \\
\hline $\mathrm{p}$ & 0.08 & 0.7 & 0.2 & 0.1 & 0.1 & 0.3 & 0.1 \\
\hline \multicolumn{8}{|l|}{$\Delta \mathrm{DBP}$} \\
\hline \multicolumn{8}{|l|}{$\mathrm{N}$} \\
\hline $\mathrm{R}$ & -0.13 & 0.32 & -0.42 & 0.31 & 0.39 & 0.38 & 0.33 \\
\hline $\mathrm{p}$ & 0.5 & 0.1 & 0.03 & 0.1 & 0.04 & 0.06 & 0.1 \\
\hline \multicolumn{8}{|l|}{ A } \\
\hline $\mathrm{R}$ & 0.10 & 0.24 & 0.16 & 0.17 & 0.05 & 0.14 & 0.16 \\
\hline $\mathrm{p}$ & 0.7 & 0.3 & 0.5 & 0.5 & 0.8 & 0.6 & 0.5 \\
\hline \multicolumn{8}{|l|}{$\Delta \mathrm{SpO}_{2}$} \\
\hline \multicolumn{8}{|l|}{$\mathrm{N}$} \\
\hline $\mathrm{R}$ & 0.06 & -0.33 & -0.05 & -0.08 & -0.34 & -0.19 & -0.09 \\
\hline $\mathrm{p}$ & 0.7 & 0.1 & 0.8 & 0.6 & 0.09 & 0.3 & 0.6 \\
\hline \multicolumn{8}{|l|}{ A } \\
\hline $\mathrm{R}$ & 0.10 & -0.08 & 0.20 & -0.29 & -0.21 & -0.36 & -0.24 \\
\hline $\mathrm{p}$ & 0.7 & 0.7 & 0.4 & 0.2 & 0.4 & 0.1 & 0.3 \\
\hline
\end{tabular}

Abbreviations as in Table 4.

A - allergic group; $\mathrm{N}$ - non-allergic group.

$\mathrm{R}$ - Spearman's rank correlation coefficient.

\section{DISCUSSION}

In this experimental study, exposure to air pollution during brief aerobic exercise was not associated with any statistically significant acute respiratory and cardiovascular responses, except for a change in FeNO found only in the subjects without upper respiratory allergy. In the allergic volunteers, FeNO changes did not seem to be related to any of the recorded environmental parameters.
Exhaled nitric oxide has been used so far in a number of studies assessing air pollution inflammatory impact [5]. Among the mechanisms in which air pollution, especially PM, may increase the exhaled nitric oxide level, epigenetic changes are most often mentioned [15]. Exposure to PM leads to a decrease in the methylation of the inducible nitric oxide synthase (iNOS) gene promoter. This results in the increased synthesis of nitric oxide by airways epithe- 
lial cells $[15,16]$. Such a mechanism could not fully explain the correlation observed in this study, as longer lags of time are required for such changes to develop. In the study cited above, the strongest effect of $\mathrm{PM}_{2.5}$ on DNA methylation and FeNO levels was found during first $6 \mathrm{~h}$ after exposure $[15,16]$. Nevertheless, the inhalation of PM may trigger other mechanisms, such as oxidative stress [1,2], eventually resulting in the induction of iNOS [17].

The impact of air pollution on FeNO increase has been shown in many studies [1,5]. However, it is more difficult to define the short-term interactions between physical activity and air pollution on FeNO levels. Increased FeNO levels were observed, e.g., directly after 5-h exposure periods with $20 \mathrm{~min} / \mathrm{h}$ of exercise in a group of healthy young adults [18]. Similarly, Kubesch et al. [12] found a positive association between increased traffic-related air pollution concentrations and increased FeNO levels, both at rest and after exercise. In contrast, a recent study by Wagner and Clark [19] did not show any dose-response relationships for $\mathrm{PM}_{2.5}$ and $\mathrm{FeNO}$ in young healthy adults when exercising outdoors.

Inconsistent outcomes of different studies may be partly a result of different exposure levels. In the aforementioned study, the $\mathrm{PM}_{2.5}$ concentrations ranged 2.1-17.7 $\mu \mathrm{g} / \mathrm{m}^{3}$. This study, which shows an association between $\mathrm{PM}_{2.5}$ and post-exercise change in FeNO in volunteers without allergy, took place in the conditions of substantially higher air pollutants levels. Those differences in airways response to different levels of exposure support the estimates by Pasqua et al. [20]. Those authors assessed the pollutant dose accumulated during aerobic exercise in 10 cleanest and 10 dirtiest cities in the WHO database, and its predicted impact on all-cause mortality. According to their results, after $15 \mathrm{~min}$ of exercise in the dirtiest cities, no more benefits of physical activity would be observed due to air pollution health risks. In the cleanest cities, after 90 min of exercise, training would still be beneficial.
The major finding in this study was that the association between air pollutant concentrations and the FeNO change after exercise was observed only in non-allergic individuals. To the best of the author's knowledge, this is the first study that shows different FeNO responses to air pollution directly after exercise in people with and without allergy. However, this difference is supported by other studies, which did not refer to physical exercise or concerned a longer physical activity pattern. In a New York-based asthma case-control study, Cornell et al. [21] observed that black carbon (BC) concentration was associated with FeNO only among non-seroatopic children. In atopic children, FeNO was strongly associated with dust-mite exposure. Those authors hypothesized that the allergic component of FeNO production may outweigh a milder air pollution impact. Lovinsky-Desir et al. [22] measured physical activity of children and their exposure to $\mathrm{BC}$ during a week. They observed a positive impact of physical activity on airways inflammation in children with low $\mathrm{BC}$ exposure. However, the positive effect of physical activity on FeNO was not observed in children suffering from asthma and in those being allergic to cockroach allergens.

In this study, no associations were observed between air pollution exposure during exercise and a decrease in spirometry parameters (especially $\mathrm{FEV}_{1}, \mathrm{FVC}, \mathrm{FEV}_{1} \% \mathrm{FVC}$ ). In contrast, such observation was made by Matt et al. [23]. However, in that case, the exercise lasted longer than in this study. Wagner and Clark [19] who examined direct post-exercise respiratory responses to brief exercise also did not observe any significant changes in $\mathrm{FVC}$ and $\mathrm{FEV}_{1}$. The strength of this study is the standardization of physical exercise. Another advantage is the fact that it was conducted in real-time winter exposure conditions. To the best of the author's knowledge, this is the first such study in Poland. Previous research on human responses to air pollution exposure during physical exercise was mainly conducted in countries with lower air pollution levels. Data 
from different regions, with varying air pollution types, are needed in order to fully explain this topic.

There are several limitations of this study. Mainly, it only consists of a single trial of the study group. Although the environmental conditions during exercise of the allergic and non-allergic groups were not different, and the exercise was standardized, conducting a series of tests in each subject, under various air pollution conditions, would provide more evidence regarding the exposure-effect association. Moreover, the study groups were relatively small. However, the published evidence is based on the results obtained in groups of similar sizes [7,9,12,19,23]. It is also possible that, within the allergic group, there were subjects with underdiagnosed asthma. It cannot be excluded that another factor which could affect the results was a relatively short duration of physical exercise. Such a suspicion deserves verification using a specific study protocol.

\section{CONCLUSIONS}

The main finding of this study is that the presence of upper-respiratory allergy may be a modifying factor in human response to air pollution during exercise. Exposure to air pollution during brief moderate-intensive exercise did not have any acute negative impact on respiratory and cardiovascular function in young healthy males. However, subclinical post-exercise changes in FeNO were observed. These changes were related to air pollution exposure only in people without allergy.

\section{ACKNOWLEDGMENTS}

The author would like to thank his scientific tutor, Prof. Jan E. Zejda.

\section{REFERENCES}

1. Thurston GD, Kipen H, Annesi-Maesano I, Balmes J, Brook RD, Cromar K, et al. Ajoint ERS/ATS policy statement: what constitutes an adverse health effect of air pollution? An analytical framework. Eur Respir J. 2017;49(1), https:// doi.org/10.1183/13993003.00419-2016.
2. Losacco C, Perillo A. Particulate matter air pollution and respiratory impact on humans and animals. Environ Sci Pollut Res. 2018;25(34):33901-10, https://doi.org/10.1007/s11356018-3344-9.

3. Kim K-H, Kabir E, Kabir S. A review on the human health impact of airborne particulate matter. Environ Int. 2015;74:136-43, https://doi.org/10.1016/j.envint.2014.10.005.

4. Giles LV, Koehle MS. The Health Effects of Exercising in Air Pollution. Sport Med. 2014;44(2):223-49, https://doi. org/10.1007/s40279-013-0108-z.

5. Annesi-Maesano I, Dinh-Xuan AT. Is exhaled nitric oxide a marker of air pollution effect? Eur Respir J.2016;47(5):13046, https://doi.org/10.1183/13993003.00521-2016.

6. Giorgini P, Rubenfire M, Bard RL, Jackson EA, Ferri C, Brook RD. Air Pollution and Exercise A Rewiev of the Cardiovascular Implications for Health Care Professionals. J Cardiopulm Rehabil Prev. 2016;36:84-95, https://doi. org/10.1097/HCR.0000000000000139.

7. Kargarfard M, Shariat A, Shaw BS, Shaw I, Lam ETC, Kheiri A, et al. Effects of Polluted Air on Cardiovascular and Hematological Parameters After Progressive Maximal Aerobic Exercise. Lung. 2015;193(2):275-81, https://doi.org/10.1007/ s00408-014-9679-1.

8. Laeremans M, Dons E, Avila-Palencia I, Carrasco-Turigas G, Orjuela-Mendoza JP, Anaya-Boig E, et al. Black Carbon Reduces the Beneficial Effect of Physical Activity on Lung Function. Med Sci Sport Exerc. 2018;50(9):1875-81, https://doi.org/10.1249/MSS.0000000000001632.

9. Kargarfard M, Poursafa P, Rezanejad S, Mousavinasab F. Effects of exercise in polluted air on the aerobic power, serum lactate level and cell blood count of active individuals. Int J Prev Med. 2011;2(3):145-50.

10. Chen X, Chen W, Wang Y, Han Y, Zhu T. Responses of healthy young males to fine-particle exposure are modified by exercise habits: a panel study. Environ Heal. 2018;17(1):88, https://doi.org/10.1186/s12940-018-0437-3.

11. Silva-Renno A, Baldivia G, Oliveira-Junior M, BrandaoRangel M, El-Mafarjeh E, Dolhnikoff M, et al. Exercise 
Performed Concomitantly with Particulate Matter Exposure Inhibits Lung Injury. Int J Sports Med. 2018;39(02):133-40, https://doi.org/10.1055/s-0043-121147.

12. Kubesch NJ, Nazelle A de, Westerdahl D, Martinez D, Carrasco-Turigas G, Bouso L, et al. Respiratory and inflammatory responses to short-term exposure to traffic-related air pollution with and without moderate physical activity. Occup Env Med. 2015;72(4):284-93, https://doi.org/10.1136/ OEMED-2014-102106.

13. Kobza J, Geremek M, Dul L. Characteristics of air quality and sources affecting high levels of PM10 and PM2.5 in Poland, Upper Silesia urban area. Environ Monit Assess. 2018;190(9):515, https://doi.org/10.1007/s10661-018-6797-x.

14. Inspekcja Ochrony Środowiska Wojewódzki Inspektorat Ochrony Środowiska w Katowicach. [Stan Środowiska w Województwie Śląskim w 2017 roku.] Katowice: Biblioteka Monitoringu Środowiska; 2018. Polish.

15. Chen R, Qiao L, Li H, Zhao Y, Zhang Y, Xu W, et al. Fine Particulate Matter Constituents, Nitric Oxide Synthase DNA Methylation and Exhaled Nitric Oxide. Environ Sci Technol. 2015;49(19):11859-65, https://doi.org/10.1021/acs. est.5b02527.

16. Shi J, Chen R, Yang C, Lin Z, Cai J, Xia Y, et al. Association between fine particulate matter chemical constituents and airway inflammation: A panel study among healthy adults in China. Environ Res. 2016;150:264-8, https://doi. org/10.1016/j.envres.2016.06.022.

17. Li H, Bai H, Yang C, Chen R, Wang C, Zhao Z, et al. Acute effects of ambient temperature and particulate air pollution on fractional exhaled nitric oxide: A panel study among diabetic patients in Shanghai, China. J Epidemiol. 2017;27(12):584-9, https://doi.org/10.1016/j.je.2017.01.002.

18. Strak M, Janssen NAH, Godri KJ, Gosens I, Mudway IS, Cassee FR, et al. Respiratory health effects of airborne particulate matter: the role of particle size, composition, and oxidative potential-the RAPTES project. Environ Health Perspect. 2012;120(8):1183-9, https://doi.org/10.1289/ehp.1104389.

19. Wagner DR, Clark NW. Effects of ambient particulate matter on aerobic exercise performance. J Exerc Sci Fit. 2018;16(1):12-5, https://doi.org/10.1016/j.jesf.2018.01.002.

20. Pasqua LA, Damasceno MV, Cruz R, Matsuda M, Garcia Martins M, Lima-Silva AE, et al. Exercising in Air Pollution: The Cleanest versus Dirtiest Cities Challenge. Int J Environ Res Public Health. 2018;15(7), https://doi.org/10.3390/ ijerph15071502.

21. Cornell AG, Chillrud SN, Mellins RB, Acosta LM, Miller RL, Quinn JW, et al. Domestic airborne black carbon and exhaled nitric oxide in children in NYC. J Expo Sci Environ Epidemiol. 2012;22(3):258-66, https://doi.org/10.1038/ jes.2012.3.

22. Lovinsky-Desir S, Jung KH, Rundle AG, Hoepner LA, Bautista JB, Perera FP, et al. Physical activity, black carbon exposure and airway inflammation in an urban adolescent cohort. Environ Res. 2016;151:756-62, https://doi.org/10.1016/j.envres.2016.09.005.

23. Matt F, Cole-Hunter T, Donaire-Gonzalez D, Kubesch N, Martínez D, Carrasco-Turigas G, et al. Acute respiratory response to traffic-related air pollution during physical activity performance. Environ Int. 2016;97:45-55, https://doi. org/10.1016/J.ENVINT.2016.10.011.

This work is available in Open Access model and licensed under a Creative Commons Attribution-NonCommercial 3.0 Poland License - http://creativecommons.org/ licenses/by-nc/3.0/pl/deed.en. 